\title{
Geomaritime-Based Marine and Fishery Economic Development in Maluku Islands
}

\author{
Atikah Nurhayati and Agus Heri Purnomo
}

Received: September 2016 / Accepted: Februari 2017 / Published online: December 2017 () 2017 Faculty of Geography UGM and The Indonesian Geographers Association

\begin{abstract}
The design of national economic development should never ignore three important aspects, namely integration, and sustainably and local contexts. Insufficient comprehension over these three aspects has caused delays of economic progress in several regions like Maluku. This region is characterized with archipelagic geo-profile where marine and fisheries resources are abundant but economic progress is sluggish. To catch up with the achievement shown by regions in the western part of the country, there must by effective efforts done in Maluku. This research is aimed at analyzing the three aspects mentioned above as related to acceleration of marine and fisheries economic development based on the region's maritime geo-profile. In line with it, primary and secondary data were applied on a SWOT Analytical Approach. Based on the analysis, it was concluded that acceleration of marine and fisheries economic development in Maluku can be carried out through both local and national policies focused on facilitating prospective economic players in making massive investment in the marine and fisheries sector. Among others, this should be done by improving the capacity of Maluku marine ports and directing them to be local economic transmiters, through more effective functions as hubs for ships carrying commodities and products for both national and international markets. This research found that in line with it, a pre-requirement that has to be advanced by the government is detailed zoning of marine and fisheries resources, which is supported by a legal umbrella.
\end{abstract}

Keywords: acceleration, economic development, marine and fisheries, geo-maritime, Maluku

\begin{abstract}
Abstrak Rancang bangun pembangunan ekonomi nasional tidak dapat mengabaikan tiga aspek penting yaitu integrasi, keberlanjutan, dan konteks lokal. Pemahaman yang rendah pada ketiga hal ini telah menyebabkan lambatnya perkembangan ekonoi di sejumlah wilayah seperti Maluku. Wilayah ini dicirikan dengan profil gerografis kepulauan dimana sumber daya kelautan dan perikanan melimpah namun perkembangan ekonomi tidak dapat berjalan cepat. Untuk mengejar tingkat perkembangan yang terjadi di wilayah-wilayah lain, terutama di bagian barat Indonesia, dibutuhkaan upaya-upaya efektif di Maluku. Penelitian ini ditujukan untuk menganalisis tiga aspek tersebut di atas dalam kaitannya dengan percepatan pembangunan ekonomi kelautan dan perikanan yang berbasis profil geografis wilayah tersebut. Data primer dan sekunder digunakan untuk melakukan analisis SWOT dalam penelitian ini. Bardasarkan analisis SWOT, disimpulkan bahwa percepatan pembangunan ekonomi kelautan dan perikanan di Maluku dapat diupayakan melalui penerapan kebijakan nasional dan daerah yang difokuskan pada fasilitasi yang dapat mendorong para pelaku ekonomi melakukan investasiinvestasi di sektor kelautan dan perikanan. Di antara upaya tersebut, salah satunya adalah melalui peningkatan kapasitas pelabuhan-pelabuhan di Maluku dan menjadikannya pendorong ekonomi lokal melalui fungsi yang efektif sebagai simpulsimpul bagi kapal-kapal pengangkut komoditas dan produk, baik untuk pasar nasional maupun global. Penelitian ini juga meyimpulkan bahwa terkait hal itu, prasyarat yang harus diwujudkan oleh pemerintah adalah pemetaan yang lebih rinci untuk sumberdaya kelautan dan perikanan, yang didukung oleh sebuah payung hukum yang efektif.
\end{abstract}

Kata kunci: geo-maritim, kelautan dan perikanan, Maluku, pembangunan ekonomi, percepatan

\section{Introduction}

Based on the UNCLOS (United Nations Convention on the Law of the Sea) 1982, Indonesia is categorized as an archipelagic state. The country meets all UNCLOS' criteria set for an archipelagic state, including that marine area coverage is not less than $50 \%$ and that distances between islands are not more than

\section{Atikah Nurhayati}

Faculty of Fisheries and Marine Science,

Agus Heri Purnomo

Padjadjaran University Socio-Economic Senior Researcher at the Agency for Marine and Fisheries Research and Development

Correspondent email: atikah.nurhayati@unpad.ac.id
100 miles, with an exception (120 miles) of up to $3 \%$. As an archipelagic country composed of $80 \%$ marine area and $20 \%$ land area, Indonesia secures a great number advantages on one side, but also faces threat to the sovereignty and territory on the other side

To Indonesia, the marine areas are expected to play important roles, including to be media to unite the nation, media of transport, media of defense and security, media diplomacy maritime, and media for economic development. Recognizing this, the country promoted a maritime state concept through Djoeanda Declaration on December 13, 1957. This declaration was then enacted by the Law No. 4/60 re. Bodies of 
Water and UNCLOS 1982

It is worth noting that the 1982 UNCLOS III establishes a comprehensive framework for the regulation and management of the ocean space. The convention consists of 320 articles and nine annexes and covers a broad spectrum of issues relating to regulation of navigation, marine protection, and scientific research and seabed. The salient features of the convention are: (a) The drawing of base lines, (b) A 12 nautical miles territorial sea, (c) Unimpeded transit passage through international straits, (d) An EEZ extending up to 200 nautical miles, (e) Continental shelf regime and rights to manage living and non-living resources of the continental shelf to a minimum of 200 nautical miles. Archipelagic baselines joining the outermost points of the outermost islands and drying reefs of the archipelago, and designate the waters within the baseline as internal waters. The baseline is also the starting point for measuring other claims such as EEZs

Indonesia's strategic geo-position is associated mainly with the fact that the country represents a busy crossroad that connects two continents, namely Asia and Australia and two oceans, namely Pacific Ocean and Indian Oceans. In addition, the strategic geo-position of Indonesia also is related with its geographical factors and the social and economic condition, all of which put Indonesia in an important position in the global environment. Such a situation makes Indonesia can affect and be affected by the political and economic stabilities, both regionally and internationally.

Later, Indonesia's maritime zones were then established in accordance with international maritime law. Territorial seas, contiguous zones, exclusive economic zones and continental shelves of Indonesia, if do not border with neighboring countries, were unilaterally set in accordance with existing regulations. In the case of borders with neighboring countries, they were established with neighboring countries in accordance with international maritime law.

And just recently, Indonesia introduced the so called Global Maritime Fulcrum (GMF). GMF focuses on five key areas, namely maritime culture, marine resources, archipelagicconnectivity, maritimediplomacy and naval development. With GMF, Indonesia wants to take advantage of being an archipelagic state / country to basically lead the global economy. The spirit of GMF certainly reflects Indonesia's interests being the world's largest archipelagic country which is, geo-strategically located at the crossroads of major power interests.

Regarding vision of being a global maritime fulcrum, Hasjim Djalal [2014] proposes that a maritime country is a country that can optimize the presence of ocean. Even a country with no ocean, as long as it can mobilizes assets including science and technology, to control and utilize ocean resources, it is considered a maritime country.
Geoffrey [2009] says that in order to be a maritime country with a power on the sea, four components should exist. These are: (1) a community that has the preference of sea (maritime community), (2) maritime resources, (3) geographical position, (4) political will. From geographical point of view, Smith [1986] suggests that this can be approached by assessment which involves three aspects and these are (1) geographical knowledge structure, (2) the application of geography in maritime management, and (3) relationship between study fields, for example between international studies and marine environmental impacts. From geography perspective, six components should exists in maritime fulcrum. These are maritime history, maritime resources, maritime social-economy, maritime culture, geoliteration, and maritime global constellation.

Indonesia to some extent already possesses basic components to be a maritime country. However, not all of the potential has been explored. The development of marine and fisheries for example, has not been tackled seriously by the government or local governments (provincial and district / city). Marine and fisheries development still faces a number of challenges such as IUU fishing, marine pollution, overexploitation, resource degradation, use conflicts and others.

There are a number of approach in developing fishery management. Marine management is that the relevant marine social organizations guide and restrict human marine development behavior by political, economic and public opinion means to protect marine environment, coordinate balanced development costal and inland. Cuif [2003] then applies an approach that is meant to promote sustainable, stable and coordinate implementations of human marine development activity and finally realize the target of harmonious co-exist between people and sea. Following such a philosophy, Huang and Shaw, 2004 adopted simultaneous equations in their assessment of the EKC using time-series data from Taiwan. The second method is referred to as a vector auto-regression (VAR) model, and was proposed by Sims as a simplified form of dynamic structural equations and a simpler alternative. And, considering the broad range of aspect characterizing fishery management, Giddens [2000] suggests that comprehensive and integrated approach should be applied, for example mention the importance of integrating environment, ecology and sociology.

Maluku is a good representative of Indonesia in the context mentioned above. This Province is an archipelagic province with almost unlimited marine resources but where all advantages have not brought significant positive impact to the people there. Recognizing this, the paper aims at analyzing aspects related to acceleration of marine and fisheries economic development based on the region's maritime geo-profile in the province. 


\section{The Methods}

The method used in this research is descriptive quantitative research with survey method. The survey, intended to map and identify field data and information, was designed to conform the research objectives and done in the location covered by the study.

The data used in this study are primary and secondary data. The methods used in collecting data was interview with respondents that were drawn through the purposive sampling and snowball sampling techniques.

Following the snowball sampling technique, information we secured at the initial step of our research was used to develop questions for the next respondent. This was iterated until the information was sufficient for analysis. Figure 1 shows the snowball sampling process diagrammatically.

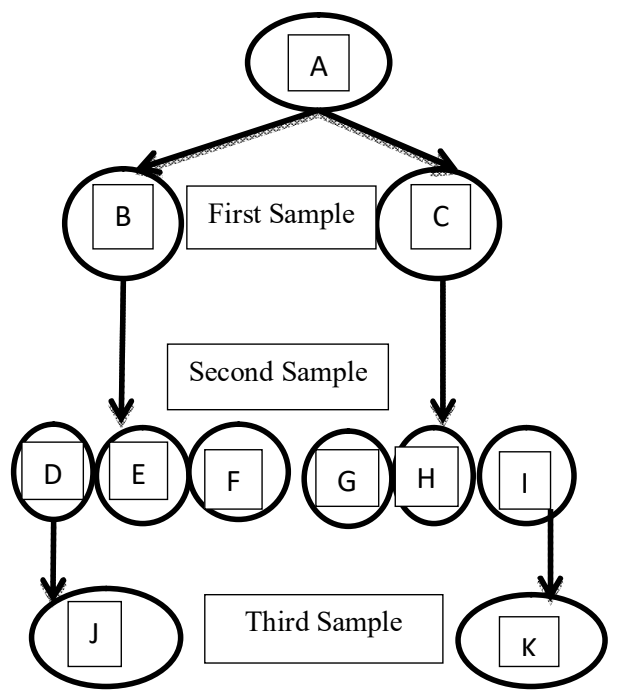

Fig 1

Snowball Sampling Method

To improve validity of data, validity tests were also performed. This was done following the procedure directed by Sugiyono [2004]. From this test, instrument accuracy was measured, Vaidity was calculated by correlating each of variable score of respondent's answer. The value of this correlation was then compated with the critical value at the significance level of 0.05 and 0.01. The formula is the Pearson Product Moment:

$r_{\text {hitung }}=\frac{n \cdot\left(\sum X Y\right)-\left(\sum X\right) \cdot\left(\sum Y\right)}{\sqrt{\left[n \cdot \sum X^{2}-\left(\sum X\right)^{2}\right] \cdot\left[n \cdot \sum Y^{2}-\left(\sum Y\right)^{2}\right.}}$

Remarks:

$\mathrm{X}=$ Valiable score

$\mathrm{Y}=$ Total of variable score

$\mathrm{n}=$ number of respondent
This analysis was used by correlating the item score with total score. Total score is the sum of all item. Validity was presented in a coefficient, namely validity coefficient. Error test on the research measurement was based on a formula of $r \geq 0,30$ [Azwar 2009]. A statement is valid if validity coefficient $\geq 0,300$ [Kaplan dan Saccuzo 1991].

Furthermore, reliability test is meant to determine a questionnaire that can be considered as an indicator of the variable. A questionnaire is considered reliable if the answer of a respondent is consisten. The Alpha is used when the score is in the scale forms (e.g., 1-4, 1-5) or range scores (e.g., 0-20, 0-50).

The formula of Alpha (Cronbach's) is

$r_{11}=\left(\frac{k}{k-1}\right)\left(1-\frac{\sum s_{i}^{2}}{s_{t}^{2}}\right)$

Remark:

$r_{11} \quad=$ instrument reliability

$$
\begin{array}{rll}
\sum s_{i}^{2} \quad \sum s_{i}^{2} & =\text { number of question item variant } \\
k & & =\text { number of question item } \\
s_{t}^{2} & s_{t}^{2} & =\text { number of total variant }
\end{array}
$$

The indicator of reliability measurement are categorized as follows:

1. if the calculated alpha or $\mathrm{r}$ equals $0.8-1.0$, the reliability is good.

2. if the calculated alpha or $r$ equals 0.6-0.799, reliability is acceptable.

3. if the calculated alpha or $r$ is less than 0.6 , reliability is not good [Sekaran 2000].

These respondents represent local government and community institutions ang other relevant stakeholders namely, academia, and the private sector. The analysis tool used is SWOT.

Following the SWOT approach, a number of internal factors (strengths and weaknesses) and external factors (opportunities and threats) were identified. Based on value measurement of strengths, weaknesses, opportunities and threats, an analysis was performed to determine strategies [Saaty, 1987]. Applying SWOT analysis, four kinds of strategies were identified: (1) S-O strategies, i.e., those that seek opportunities and take maximum advantage of the strength points; (2) W-O strategies, i.e., those applied to overcome weaknesses, so that opportunities could be benefited; (3) S-T strategies, 
i.e., those that are used such that they could minimize risk taking from threats; (4) W-T strategies, which are totally defensive strategies, wherein damages due to weaknesses against threats from external environment are minimized.

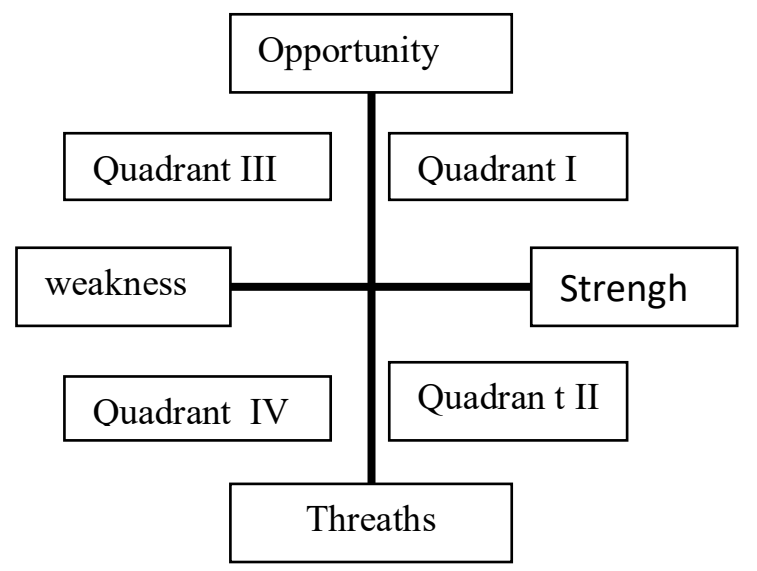

Figure 2.SWOT Quadrant

Supporting the Aggressive Strategy (Quadrant 1): This relates to a very favorable situation, meaning that the opportunity and strength are there. In this case, the strategy to be implemented is to support a policy of aggressive growth (Growth Oriented Strategy). Supporting the Diversification Strategy (Quadrant II): In this condition, a variety of threats exists, however internally there are considerable strengths. The strategy relevant to this condition is to use strength to optimize long term opportunity by implementing the diversification strategy. Supporting the Turn Around Strategy (Quadrant III): In this case, opportunities are a lot, however there is a significant weakness. For this situation, the appropriate strategy is to handle problems related to the existing weakness such that opportunities van be optimized. Supporting the Defensive Strategy (Quadrant IV): This is the most unfavorable situation, where both threats and weakness exist. For this situation, a defensive strategy is the most appropriate one

\section{Result and Discussion}

a. Geo-maritime setting of Maluku as associated with marine and fishery development

Maluku province with the capital city of Ambon, is astronomically located between $2^{\circ} 30^{\prime}$ ' $8^{\circ} 30^{\prime}$ latitude and $124^{\circ} 00^{\prime}-135^{\circ} 30^{\prime} \mathrm{E}$ (Figure 2.1). Maluku province is geographically bounded by North Maluku and Seram Sea in the north, on the east by the province of Papua, southeast Sulawesi and Central Sulawesi in the west and the Democratic Republic of Timor Leste, Australia, Indonesia Ocean and Arafura Sea in the south

The total area of $646,295 \mathrm{~km} 2$ region is composed of the territorial waters and the land area which is formed of 1,412 islands (the analysis, 2005). Maluku province has a dominant condition territorial waters about $90 \%$. Comparison between the area of land and sea area is 1: 9. The largest island is the island of Seram (18 625 $\mathrm{km} 2)$ and Buru Island $(9,000 \mathrm{~km} 2)$, Yamdena $(5,085$ $\mathrm{km} 2)$ and Wetar Island $(3624 \mathrm{~km} 2)$. Maluku province is very open access to interact with the surrounding provinces, even very open to international trade lanes, considering its existence as a liaison trade between North and South.Climate in the Maluku islands are tropical climate and monsoon climate, because the area is surrounded by vast seas. Thus, the climate is strongly influenced by a vast ocean. Maluku region recognizes two seasons namely: season west or north and south or east punctuated by two kinds of transition which is the second transition season. West monsoon in the Moluccas lasted from December to March, while April is the transition to the southeast of the season. Season southeast apply an average of 6 months starting from the month of May and ends in October. The transition to the west season is in November. Seasonal conditions are not homogenous in the sense that every season prevailing in the area.

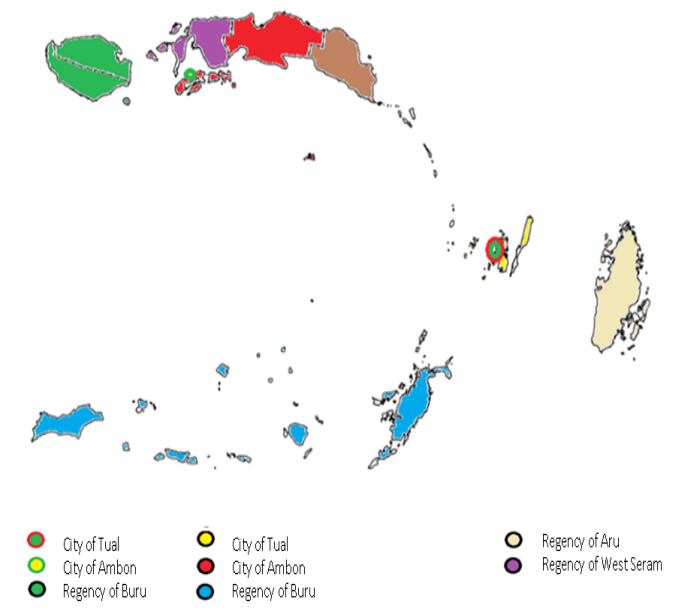

Figure. 3 Maluku Island 
The mangrove ecosystem very important role in supporting the balance of coastal ecosystem, its function as a barrier coastal erosion, as well as spawning habitat, enlargement and feeding grounds wide variety of marine life. Development of mariculture and tourism businesses in the surrounding area will impact on the mangrove forests of mangrove forest destruction, resulting in loss of coastal protection and / habitat for marine life in coastal. Sea-based resources are being exploited to meet the ever-growing demand. As a matter of fact, the seas have become the last reservoir of resources. Sea based resources can be divided into at least four categories: (a) Hydrocarbon like oil and gas. (b) Food (fish, plankton, salt, seaweed).(c) Metals (manganese, copper, gold, coal, tin, etc). (d) Other resources (sand, gravel, calcium and poly-metallic sulphides).

\section{b. Validity and Reliability Tests}

From the total of 20 items of external and internal factors in the SWOT Analysis, the value of validity coefficient is $>0.300$. Referring to Kaplan and Saccuzo [1991], this means that the factors are valid and can be proceeded for further analysis.

Meanwhile, from the same total 20 items, it was found that a value is 0.812 , which is greater than 0.6 . Referring to Malhotra [2007], this means that the factors are reliable.

\section{c. SWOT Analysis}

As suggested in the background, geomaritimebased marine and fishery economic development in maluku islands, the analysis was carried out accordingly. In SWOT analysis, the following Streghts, Weakness, Opportunity, Threat factors were identified during the field work. Strength factors were: Energy and mineral mining the seabed, has a very high economic value (S1), the potential of fishery resources (S2), islands which is a path national and international transport (S3), the potential for marine tourism (S4), marine growth centers development primary (S5). Weakness factors were: human resources remains low (W1); low investment in the fisheries and marine sector (W2); lack of conservation (W3); conflict of interest (W4); natural resource management (W5). Table 1 shows the values of weight, ranking and the respective scores of these strength and weakness factors.

It is shown in Table 1 that the highest score among other strength factors is the score of The existence of marine tourism economic potential (S4) 0.52 , the abundance of fishery resources potential (S2) 0.48 , the potential of fishery resources, production of economically important fish in the pelagic fish group dominated species of fish, namely: (1) Katsuwonus pelamis or Skipjack tuna this fish is one large pelagic fish species that have economic value is important. Area deployment of skipjack in almost all waters
Maluku province; (2) Euthynnus affinis this fish is one type of pelagic fish the important economic value: (3) Rastrelliger spp. This fish is a small pelagic fish swim in groups and is one of economic fish important

The fact that there are many islands that can function as paths for national and international transport (S3) 0.30 Good connectivity between regions in Indonesia will be able to facilitate the movement of people, goods, services and capital. Marine Growth Centers Development Primary (S5) 0.30, the potential for marine tourism 0.30; Energy and mineral mining the seabed has a high economic value (S1) 0.30. Indonesia must continue to provide the data, textual and geospatial either in the form of geological maps, oceanographic, hydrographic and biodiversity, as well as on the content of the contents wealth of the homeland in the waters of Indonesia, especially at sea in Indonesia. In the mean time, Table 1 shows the values of weight, ranking and the respective scores of opportunities and threats factors.

It is shown in Table 2 that the highest score among other opportunity factors is the score of Geostrategic position which has three Indonesian archipelagic sea lanes (O1) 0.48, the Indonesian archipelago with geostrategic position that has three Indonesian archipelagic sea lanes (ALKI) and five regions choke points (the Strait of Malacca, Singapore Straits, the Strait of Sunda, Lombok Strait, and Strait Ombai-Wetar) which also must respect the freedom of sailing requires the support system strong defense and security

Various forms and nature of the threat may occur at sea, such as various shipping lines that can be passed nuclear submarine foreign, are vulnerable to acts of armed violence at sea, arms smuggling, slavery at sea, smuggling, human trafficking, destruction of marine resources, theft underwater cultural heritage, and theft of marine resources. Hence the doctrine of defense and security "Minimum Essential Force" should be developed, so we need a doctrine and posture of defense and security in accordance with an area of sovereignty and sovereign rights of Indonesia.

Security challenges of traditional and nontraditional small islands, outermost and isolated, Indonesian maritime economy not only from the wealth of natural resources and non-biodiversity, but also should develop in the field of port logistics services commercial ships and yachts, marine tourism. authority to the Provincial Government for managing maritime resources and small islands and outermost within a radius of 12 nautical miles and the rights of county and city to get for marine products in the territory of 4 Nautical Miles and measurably involvement of local government and communities in the area of maritime surveillance. It needs special attention in the design of central and local government relations with the community and the government in relation to the design of national and regional institutions. 
National marine policy should also refer to the six basic principles, namely (1) the insights of the archipelago; (2) sustainable development; (3) The blue economy; (4) management of integrated and transparent; (5) participation; and (6) equality and equity.

Table 1. Matrix of Internal Factor Strategy Analysis

\begin{tabular}{|c|c|c|c|}
\hline Internal Factors & Weight & Ranking & Score \\
\hline \multicolumn{4}{|l|}{ Streghts } \\
\hline $\begin{array}{l}\text { 1. The existence of high economic potential that can be derived from } \\
\text { energy and seabed mineral mining }(\mathrm{S} 1)\end{array}$ & 0.07 & 3 & 0.21 \\
\hline 2. The abundance of fishery resources potential (S2) & 0.12 & 4 & 0.48 \\
\hline $\begin{array}{l}\text { 3. The fact that there are many islands that can function as paths for } \\
\text { national and international transport (S3) }\end{array}$ & 0.10 & 3 & 0.30 \\
\hline 4. The existence of marine tourism economic potential (S4) & 0.13 & 4 & 0.52 \\
\hline 5. The presence of the Marine Growth Development Centers (Primary S5) & 0.10 & 3 & 0.30 \\
\hline Weakness & & & 1.55 \\
\hline 1. Human Resources remains low (W1) & 0.12 & 3 & 0.36 \\
\hline 2. Investment in the fisheries and marine sector is low (W2) & 0.11 & 4 & 0.44 \\
\hline 3. Effective conservation is lacking (W3) & 0.09 & 3 & 0.27 \\
\hline 4. Conflict of interest remains undergoing (W4) & 0.07 & 3 & 0.21 \\
\hline 5. Natural resource management is not optimal (W5) & 0.09 & 3 & 0.27 \\
\hline Total Internal Factor & 1 & & 3.36 \\
\hline
\end{tabular}

Development in the Maluku Island capitalize marine resources as a complement and mutually reinforce each other synergistically. Ocean becoming very large development capital. However the complexity of the maritime sector into a characteristic and the fact that must be faced by the stakeholders (stakeholders).

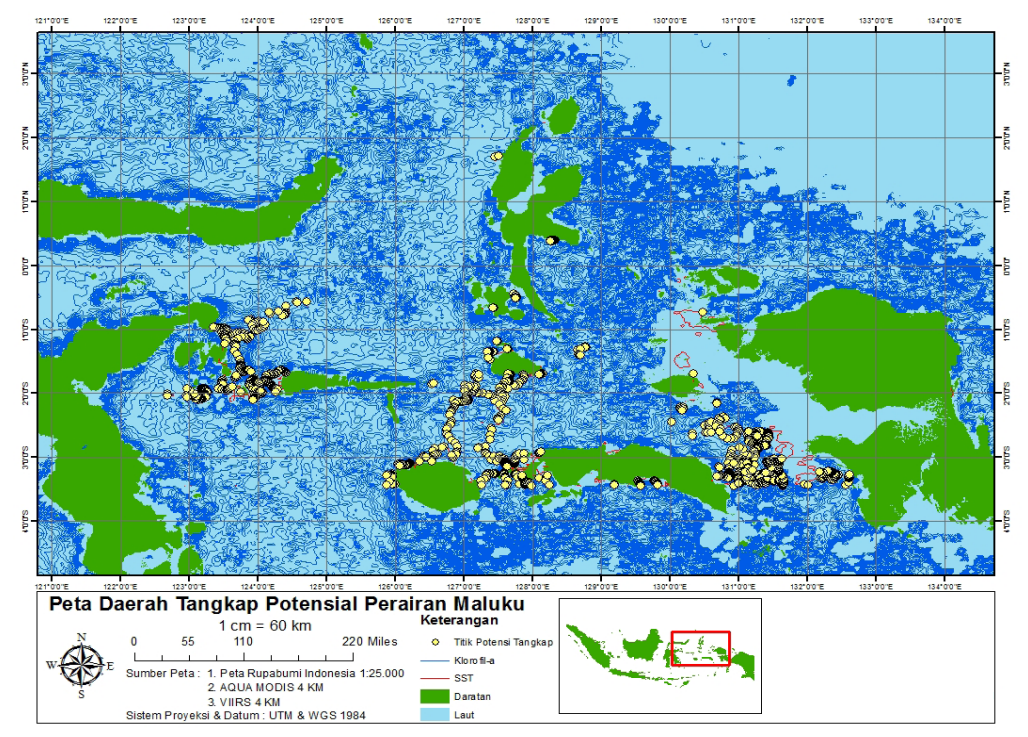

Figure 4. Capture Fisheries of Maluku Island Source: Faculty of Fisheries and Marine Science, Padjadjaran University 
The development strategy of the Maluku Islands Geomartime more focused on marine and fisheries sector in the short term is known as a sector that could have an impact on production activities from other sectors (Output Multiplier / OM) and the improvement of people's income (Income Multiplier / IM). It adds to the belief that the marine and fisheries sector can support the economy of the province of Maluku. Efforts are needed to solve these problems is the involvement of all stakeholders both communities, governments, and businesses in order to accelerate the development of marine and fisheries sector in the province of Maluku. Developning maritime connectivity to eliminate social and economic inequalities and to perform various interest both among local governments by the central government such as governance, security, trade, education, health, and communication.

Table 2. Matrix of External Factor Strategy Analysis

\begin{tabular}{|c|c|c|c|}
\hline External factors & Weight & Ranking & Score \\
\hline \multicolumn{4}{|l|}{ Opportunities } \\
\hline $\begin{array}{l}\text { The existence of good geostrategic position, where Indonesia has three } \\
\text { archipelagic sea lanes (ALKI) (O1) }\end{array}$ & 0.12 & 4 & 0.48 \\
\hline $\begin{array}{l}\text { The existence of authority given to the Provincial Government for } \\
\text { managing maritime resources and small and outer..most islands within a } \\
\text { radius of } 12 \text { nautical miles }(\mathrm{O} 2)\end{array}$ & 0.11 & 3 & 0.33 \\
\hline $\begin{array}{l}\text { The acquisition and utilization of marine science and technology through } \\
\text { higher education to increase research and development capacity (O3) }\end{array}$ & 0.12 & 3 & 0.36 \\
\hline The existence of economic value potential from marine tourism (O4) & 0.08 & 3 & 0.24 \\
\hline The establishment of Maluku as a National Fish Barn (O5) & 0.07 & 4 & 0.28 \\
\hline \multicolumn{4}{|l|}{ Threat } \\
\hline $\begin{array}{l}\text { The development of potential and function of small islands group as a } \\
\text { driver of economic activity (T1) }\end{array}$ & 0.11 & 4 & 0.44 \\
\hline Human trafficking (T2) & 0.11 & 2 & 0.22 \\
\hline Underwater cultural heritage and marine resources vandalism (T3) & 0.08 & 3 & 0.24 \\
\hline Shipping lines may be crossed foreign nuclear submarine (T4) & 0.10 & 2 & 0.20 \\
\hline Threats that damage fisheries resources (T5) & 0.10 & 3 & 0.30 \\
\hline Total External Factors & 1 & & 4.93 \\
\hline
\end{tabular}

Based on the SWOT analysis of the information obtained Geomaritime-Based Marine and Fishery Economic Development in Maluku Islands are at quadrant 1 Supporting the Aggressive Strategy. An aggressive strategy accordingly should be carried the optimization of fisheries and marine resources, including the marine tourism and trade paths

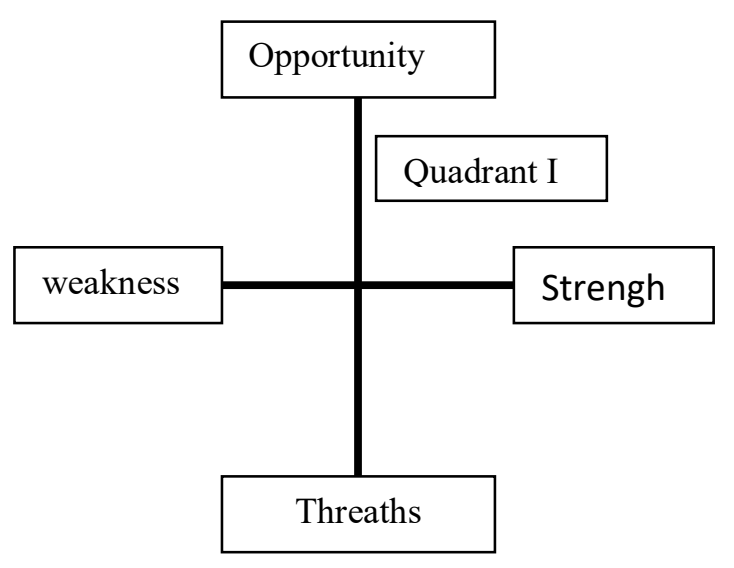

Figure 5.Quadrant SWOT Analysis 


\begin{tabular}{|c|c|c|}
\hline & Streghts (S) & Weakness (W) \\
\hline Eksternal & $\begin{array}{l}\text { The existence of high economic } \\
\text { potential that can be derived from } \\
\text { energy and seabed mineral mining } \\
\text { The abundance of fishery resources } \\
\text { potential } \\
\text { The fact that there are many } \\
\text { islands that can function as paths } \\
\text { for national and international } \\
\text { transport } \\
\text { The existence of marine tourism } \\
\text { economic potential } \\
\text { The presence of the Marine Growth } \\
\text { Development Centers }\end{array}$ & $\begin{array}{l}\text { Human Resources remains low } \\
\text { Investment in the fisheries and } \\
\text { marine sector is low } \\
\text { Effective conservation is lacking } \\
\text { Conflict of interest remains } \\
\text { undergoing } \\
\text { Natural resource management is } \\
\text { not optimal }\end{array}$ \\
\hline $\begin{array}{l}\text { Opportunities }(\mathrm{O}) \\
\text { The existence of good geostrategic } \\
\text { position, where Indonesia has three } \\
\text { archipelagic sea lanes } \\
\text { The existence of authority given } \\
\text { to the Provincial Government for } \\
\text { managing maritime resources and } \\
\text { small and outermost islands within } \\
\text { a radius of } 12 \text { nautical miles } \\
\text { The acquisition and utilization of } \\
\text { marine science and technology } \\
\text { through higher education to } \\
\text { increase research and development } \\
\text { capacity } \\
\text { The existence of economic value } \\
\text { potential from marine tourism } \\
\text { The establishment of Maluku as a } \\
\text { National Fish Barn }\end{array}$ & $\begin{array}{l}\text { S-O Strategy: } \\
\text { Taking advantages including the } \\
\text { world's strategic trade routes, the } \\
\text { existence of provincial authority, } \\
\text { to create maximum values from } \\
\text { exploitation of all available } \\
\text { resources }\end{array}$ & $\begin{array}{l}\text { Strategi W-O } \\
\text { Taking care of and mitigating the } \\
\text { impact of low human resources, } \\
\text { resource degradation, and } \\
\text { conflict of interests such that } \\
\text { resource exploitation can be } \\
\text { made optimal }\end{array}$ \\
\hline $\begin{array}{l}\text { Threat (T) } \\
\text { The development of potential and } \\
\text { function of small islands group as a } \\
\text { driver of economic activity } \\
\text { Human trafficking } \\
\text { Underwater cultural heritage and } \\
\text { marine resources vandalism } \\
\text { Shipping lines may be crossed } \\
\text { foreign nuclear submarine } \\
\text { Threats that damage fisheries } \\
\text { resources }\end{array}$ & $\begin{array}{l}\text { Strategi S- T } \\
\text { Taking advantage of the abundance } \\
\text { resources to optimize long term } \\
\text { opportunities by implementing the } \\
\text { steps that can minimize internal } \\
\text { problems such as vandalism, and } \\
\text { resource degradation }\end{array}$ & $\begin{array}{l}\text { Strategi W-T } \\
\text { Mitigating the impact of all } \\
\text { weakness including low human } \\
\text { resources, resource degradation, } \\
\text { and conflict of interests such } \\
\text { that resource exploitation can be } \\
\text { made optimal and and internal } \\
\text { problems such as vandalism and } \\
\text { resource degradation to keep } \\
\text { future opportunities open. }\end{array}$ \\
\hline
\end{tabular}

Reviewed swot analysis can be seen several threatsTrafficking and Smuggling The sea is the main medium for the illegal movement of people and goods because larger shipments can be carried, covert transhipment is possible at sea and maritime borders are more porous than land and air borders. its own network of human intelligence and transnational organization [Karsten,2011]. Threats that damage fisheries resources, so it should be done fishery and marine resources conservation to promote sustainable development. 


\section{Conclusions}

Through a swot analysis can be concluded that the accelerated development of marine and fisheries economy in Maluku can be done through an aggressive strategy either through local and national policies focused on facilitating economic actors candidate in making massive investments in marine and fisheries sector. Among other things, this should be done by increasing the capacity of the Maluku sea ports and directs them to become transmiters local economy, through more effective function as a relationship for ships carrying commodities and products to national and international markets. This study found that in line with the pre-requisites that must be filed by the government is the detailed zoning of marine and fishery resources.

\section{References}

Badan Informasi Geospasial (2015). Strategi Mewujudkan Indonesia Sebagai Poros Maritim Dunia dalam Perspektif Geografi. (in Bahasa Indonesia).

Cuif Wangqs,(2003). Sociological Interpretations marine management . Journal of Ocean Unoversity of China (Social Science) .

Djalal, Hasjim. (2014). Negara Maritim dan/atau Negara Kepulauan? 7 November 2014. http:// news.metrotvnews. om/read/2014/11/07/315756/ negara-maritim-dan-atau-negara-kepulauan. html. (in Bahasa Indonesia).

Gidden, (2000).Consequence of moderenity. Tianh (translator) Nanjing.Yilin Press.2000. United Nations, The Law OfThe Sea (LOS) (New York: UN, 1983), p.192.

Hu, D.; Xu, K.P.; Yang, J.X.; Liu, T.X. (2004). Economic development and environmental quality: Progress on the environmental Kuznets curve. Acta Ecol. Sinica, 24, 1259-1266

Karsten von Hoesslin, (2011). Smuggling in South East Asia: Dynamically fluid, Strategic Insights 31 (March 2011): 17-23.

Saaty, R. W., (1987). The analytic hierarchy process and SWOT analysis- what it is and how it is used. Math. Model 9, 161 - 178 p.192.

Smith, Hance D. (1986). The Geography of the Sea. Geography, Vol. 71(4), 320-324.

Till, Geoffrey (2009). Seapower: A Guide for the Twenty-First Century. Third Edition. London: Routledge

United Nations (1982). United Nations Convention on the Law of the Sea of 10 December 1982, http:// www.un.org/Depts/los/convention agreements/ convention_overview_convention.htm
Gwalema, Susan Rugano. (2011). Impacts of urban development pressure on coastal local communities in Tanzania. Indonesian Journal of Geography. Vol. 43, No. 2, December 2011 (123 - 141).

Widianto Arief and Michiel Damen (2014). Determination of Coastal Belt in the Disaster Prone Area: A case study in the Coastal area of Bantul Regency, Yogyakarta, Indonesia. Indonesian Journal of Geography Vol. 46, No.2, December 2014 (125 - 137).

Qu Qunzhen and Qongjiang Xu. (2013). Exploration on Marine Management Under the View Marine Eco-civilitation. Metereological and Environmental Research. 2013, 4(12) : 31-32, 38. 